\title{
The new (XVIIIth) International Congress of Zoology Le nouveau (XVIIIme) Congrès International de Zoologie
}

First Announcement

The date of the new Congress has been set for 4-9 September 2000 and the venue will be the Faculty of Philosophy, at the University of Athens, Greece, under the auspices of the Hellenic Zoological Society.

In order to reverse the present trend of fragmentation of Zoology and the crisis in the professional zoological education that became rampant after the suspension of the Congresses in 1972, we have decided to dedicate this first renewed Congress mainly to a number of integrative symposia and general discussions.

We call upon you to participate !

Please inform us till mid-October 1998 about your intention to participate and/ or receive further information contaiped in our First Circular, contacting Dr. Rosa Polymeni, University of Athens, Department of Biology, Section of Zoology and Marine Biology, 15784 Athens, Greece, Tel. +30.1.7264364, Fax +30.1.7284604 (e-mail: rpolyme@biology.db.uoa.gr)

The text of the First Circular can be accessed and copied also from our page in http://www.york.biosis.org/zrdocs/new icz. 